\title{
Selective ablation of mast cells or basophils reduces peanut- induced anaphylaxis in mice
}

\author{
Laurent L. Reber, Ph.D. ${ }^{1}$, Thomas Marichal, D.V.M., Ph.D. ${ }^{1}$, Kaori Mukai, Ph.D. ${ }^{1}$, Yoshihiro \\ Kita, Ph.D. ${ }^{2}$, Suzumi M. Tokuoka, Ph.D. ${ }^{2}$, Axel Roers, M.D. ${ }^{3}$, Karin Hartmann, M.D. ${ }^{4}$, Hajime \\ Karasuyama, Ph.D. ${ }^{5}$, Kari C. Nadeau, M.D., Ph.D. ${ }^{6}$, Mindy Tsai, D.M.Sc. ${ }^{1}$, and Stephen J. \\ Galli, M.D. ${ }^{1,7}$ \\ ${ }^{1}$ Department of Pathology, Stanford University School of Medicine, Stanford, CA, USA \\ ${ }^{2}$ Department of Lipidomics, Faculty of Medicine, The University of Tokyo, Tokyo, Japan \\ ${ }^{3}$ Institute for Immunology, University of Technology Dresden, Medical Faculty Carl-Gustav Carus, \\ Dresden, Germany \\ ${ }^{4}$ Department of Dermatology, University of Cologne, Cologne, Germany \\ ${ }^{5}$ Department of Immune Regulation, JST, CREST, Tokyo Medical and Dental University, \\ Graduate School of Medical and Dental Sciences, Tokyo, Japan \\ ${ }^{6}$ Division of Immunology and Allergy, Stanford University School of Medicine, Stanford, CA, USA \\ ${ }^{7}$ Department of Microbiology and Immunology, Stanford University School of Medicine, Stanford, \\ CA, USA
}

\section{Abstract}

Background-Studies using c-kit mutant mast cell (MC)-deficient mice and antibody-mediated depletion of basophils suggest that both MCs and basophils can contribute to peanut-induced anaphylaxis (PIA). However, interpretation of data obtained using such approaches is complicated because c-kit mutant mice have several phenotypic abnormalities in addition to MC deficiency and basophil-depleting antibodies can also react with MCs.

Objective-We analyzed: (1) the changes in the features of PIA in mice after the selective and inducible ablation of MCs or basophils, and (2) the possible importance of effector cells other than MCs and basophils in the PIA response.

Methods-Wild-type (WT) and various mutant mice were orally sensitized with peanut extract and cholera toxin weekly for 4 weeks and challenged intraperitoneally with peanut extract 2 weeks later.

Results-Peanut-challenged MC-deficient $\mathrm{Kit}^{\mathrm{W}-\mathrm{sh} / \mathrm{W} \text {-sh }}$ mice developed reduced immediate hypothermia, as well as a late phase drop in body temperature that was abrogated by antibody-

(C) 2013 American Academy of Allergy, Asthma and Immunology. Published by Mosby, Inc. All rights reserved.

Correspondence author and reprint requests: Stephen J. Galli, M.D., Department of Pathology, Lane Building, L-235, Stanford University School of Medicine, 300 Pasteur Drive, Stanford, CA 94305-5324, Phone: 650-723-7975, Fax: 650-725-6902, sgalli@stanford.edu.

Publisher's Disclaimer: This is a PDF file of an unedited manuscript that has been accepted for publication. As a service to our customers we are providing this early version of the manuscript. The manuscript will undergo copyediting, typesetting, and review of the resulting proof before it is published in its final citable form. Please note that during the production process errors may be discovered which could affect the content, and all legal disclaimers that apply to the journal pertain.

Conflict of Interest:

The authors state no conflict of interest. 
mediated depletion of neutrophils. Diphtheria toxin-mediated selective depletion of MCs or basophils in Mcpt5-Cre; iDTR and McptsDTR mice, respectively, and treatment of WT mice with the basophil-depleting antibody Ba103, significantly reduced peanut-induced hypothermia. Non-ckit mutant MC- and basophil-deficient Cpa3-Cre; $M c l-1^{f l / f l}$ mice developed reduced, but still significant, responses to peanut.

Conclusion-Inducible and selective ablation of MCs or basophils in non-c-kit mutant mice can significantly reduce PIA, but partial responses to peanut can still be observed in the virtual absence of both cell types. The neutrophilia in $\mathrm{Kit}^{W-s h / W-s h}$ mice may influence the responses of these mice in this PIA model.

\section{Keywords}

Peanut; allergy; neutrophils; diphtheria toxin; $K i t^{W-s h / W-s h}$; mast cells; anaphylaxis; basophils; carboxypeptidase A3 (CPA3); mast cell protease 5 (MCPT5)

\section{INTRODUCTION}

Food allergies are adverse acquired immune responses to food constituents, in most cases, proteins. ${ }^{1}$ Their prevalence has recently increased and food allergies now affect $\sim 6 \%$ of children and 3-4\% of adults in developed countries. ${ }^{1}$ In the U.S.A., the majority of cases of food-induced fatal or near-fatal anaphylaxis are caused by peanuts or tree nuts. ${ }^{2,}{ }^{3}$ It is estimated that peanut allergy affects $0.5-1 \%$ of the general population in Westernized countries $^{4}$ and in the U.S.A. peanut allergy increased $\sim 2$ fold from 1997 to $2002^{5}$ and now affects $\sim 1 \%$ of children. ${ }^{1}$

Basophils and mast cells (MCs) are regarded as major effector cells in allergic disorders and in anti-helminth immunity. ${ }^{6-12}$ Several lines of evidence suggest that both MCs and basophils can contribute to systemic anaphylaxis in humans ${ }^{13-15}$ and multiple pathways of anaphylaxis have been described in mice. Previous work has provided evidence that MCs can make major contributions to IgE-dependent passive systemic anaphylaxis (PSA) in mice but are not necessary for $\mathrm{IgG}_{1}$-dependent PSA. ${ }^{16-18}$ However, studies by Finkelman et al have characterized two pathways of anaphylaxis in mice: a classical pathway consisting of antigens, IgE, Fc $\in$ RI, MCs and histamine, and an alternative pathway consisting of $\operatorname{IgG}_{1^{-}}$ antigen immune complexes, FcyRIII, macrophages and platelet-activating factor (PAF). ${ }^{19}$ Tsujimura et al have identified yet a third pathway that is mediated by IgG, basophils, and basophil-derived PAF. ${ }^{18}$ More recently, Jönsson and collaborators showed that neutrophils also can contribute to certain models of anaphylaxis in mice through an IgG-FcyRIVmediated pathway. ${ }^{20}$

Evidence for many MC functions in innate and acquired immunity, including in models of food allergy and anaphylaxis, has been obtained by studying such responses using c-kit mutant MC-deficient mice, mainly $\mathrm{WBB} \mathrm{F}_{1}-\mathrm{Kit}^{W / W-V}\left(K i t^{W / W-V}\right)$ and C57BL/6$K i t^{W-s h / W-s h}\left(K i t^{W-s h / W-s h}\right)$ mice. ${ }^{12,15,21-25}$ Both $\mathrm{Kit}^{W / W-V}$ mice and $\mathrm{Kit}{ }^{W-s h / W-s h}$ mice are profoundly deficient in MCs but also have several other phenotypic abnormalities, including some affecting hematopoietic cells that contribute to innate or adaptive immune responses. ${ }^{23-29}$ For example, $\mathrm{Kit}^{W-s h / W-s h}$ mice have increased numbers of neutrophils ${ }^{27-29}$ and basophils. ${ }^{29}$

Because of the potential complexities and caveats inherent in interpreting findings based on work employing c-kit mutant MC-deficient mice, several groups have sought to develop ckit-independent MC-deficient mice, ${ }^{30-33}$ and the relative merits of these newer MCdeficient mice to the older models have been discussed in three recent reviews. ${ }^{23-25}$ The severely MC-deficient $C p a 3-C r e ; M c l-1^{f l / f l}$ mice, which we recently generated, also have a 
marked deficiency in basophils under steady-state conditions; by contrast, except for a mild anemia, the numbers of other major hematopoietic cell populations exhibit no significant differences versus those in WT mice. ${ }^{33}$

A common limitation affecting all strains of mice with a constitutive deficiency in MCs is that the effects of a constitutive deficiency of MCs on certain biological responses may be different than those observed when the MCs are ablated just before or during the response. Such inducible ablation of MCs is now possible, using Mcpt5-Cre; iDTR mice. ${ }^{31}$ These mice express the Cre recombinase under the control of the MC protease 5 (Mcpt5) promoter that is specific for connective tissue-type MCs (CTMCs) $)^{34}$, and a Cre-inducible floxed diphtheria toxin (DT) receptor transgene. As a result, the DTR transgene is expressed in CTMCs only in $M c p t 5-\mathrm{Cre}^{+}$; iDTR $^{+}$mice and injection of DT in these mice results in selective and marked reductions in numbers of CTMCs. ${ }^{31}$

The functions of basophils in vivo have long been difficult to characterize due to the lack of basophil-deficient animals. Antibody-based approaches have been used to deplete basophils in mice. ${ }^{35-38}$ However, these antibodies have been shown to react with MCs also. ${ }^{35-37}$ Thus, this approach can give results that are difficult to interpret in the case of food allergy models or other biological responses in which MCs are likely to contribute to the pathology. An alternative and more definitive model for identifying basophil functions has been introduced recently by Wada et al, who generated the first inducible basophil-deficient mice, which express the DT receptor under the control of the MC protease 8 (Mcpt8) promoter, which is specific for the basophil lineage. ${ }^{39}$

In this study, we tested the potential benefit of selectively targeting MCs or basophils in food anaphylaxis by assessing the effects of DT-induced selective ablation of MCs or basophils in a mouse model of peanut-induced anaphylaxis (PIA). We also compared the results obtained with these mice to those obtained in c-kit mutant MC-deficient animals or using antibodies to deplete basophils. Finally, we analyzed the possible roles of other effector cells in this PIA model using non-c-kit mutant MC- and basophil-deficient $C p a 3-$ Cre; $M c l-1^{f l / f l}$ mice.

\section{METHODS}

\section{Mice}

C57BL/6J mice and iDTR mice (C57BL/6-Gt(ROSA)26Sor tm1(HBEGF)Awai/J) were purchased from Jackson Laboratories (Bar Harbor, Me). C57BL/6-Kit $t^{W-s h / W-s h}$ mice were originally provided by Peter Besmer (Molecular Biology Program, Memorial SloanKettering Cancer Center, New York, NY, USA); we then backcrossed these mice to C57BL/ $6 \mathrm{~J}$ mice for more than 11 generations. ${ }^{29} \mathrm{Mcpt}{ }^{D T R}$ mice, ${ }^{39} \mathrm{Mcpt5}-\mathrm{Cre}$ mice, ${ }^{31,34}$ and Cpa3-Cre; $\mathrm{Mcl}-\mathrm{fl}^{\mathrm{fl} / \mathrm{fl}}$ mice (and the corresponding control Cpa3-Cre; $\mathrm{Mcl}-1^{+/+}$mice $)^{33}$ on the C57BL/6 background, like all of the other mice used in our experiments, were bred and maintained at the Stanford University Research Animal Facility. See Online Repository for additional details.

\section{Peanut-induced anaphylaxis (PIA) model}

Mice were sensitized with $10 \mathrm{mg}$ peanut extract (clinical-grade preparations used for skin testing; Greer Laboratories) along with $20 \mu \mathrm{g}$ of cholera toxin (Sigma-Aldrich) in $100 \mu \mathrm{L}$ of water by oral gavage once a week for 4 weeks. Before each gavage, mice were deprived of food for $3 \mathrm{~h}$. Two weeks after the last sensitization with peanut extract, mice were challenged by the intraperitoneal (i.p.) injection of $5 \mathrm{mg}$ of crude peanut extract (Greer Laboratories) in $200 \mu \mathrm{L}$ of PBS. Rectal temperature measurements were performed 
immediately before (time 0 ) and at different time points for up to $24 \mathrm{~h}$ after challenge with peanut.

\section{Other methods}

Please see this article's Online Repository at www.jacionline.org for the methods for depletion of MCs, basophils, and neutrophils, flow cytometry, evaluation of MC numbers in the peritoneal cavity, histologic analysis, and measurement of peanut-specific $\operatorname{IgE}$ and $\operatorname{IgG}_{1}$ antibodies in sera.

\section{Statistical analyses}

Results represent mean \pm SEM or mean + SEM. An unpaired Student $t$ test was used to assess the significance of differences between two sets of data. $P$ values $<0.05$ are considered statistically significant.

\section{RESULTS}

\section{Peanut-induced anaphylaxis (PIA) in ckit mutant MC-deficient mice}

We first assessed the response of c-kit mutant MC-deficient C57BL/6J-Kit ${ }^{W-s h} / W-s h$ $\left(K i t^{W-s h / W-s h}\right)$ mice in this PIA model. PN-sensitized WT and $K i t^{W-s h / W-s h}$ mice exhibited similar levels of PN-specific IgE and $\mathrm{IgG}_{1}$ antibodies in the serum (see Fig E1 in the Online Repository). $K i t^{W-s h / W-s h}$ mice developed reduced (although still significant) hypothermia as compared to WT mice during the first hour after PN challenge and none of the mice died (3/18 WT mice died in this set of experiments) (Fig 1, $A$ ). Surprisingly however, the $K i t^{W-s h / W-s h}$ mice developed a 'late phase' of hypothermia (between 3-6 hours post challenge) (Fig 1, $A$ ).

\section{Neutrophils contribute to the 'late phase' component of PIA in $K i t^{W-s h} / W$-sh mice}

Because $K i t^{W-s h / W-s h}$ mice have a neutrophilia at baseline ${ }^{27-29}$ (Fig 1, B and $C$ ) and neutrophils have recently been implicated in certain active systemic anaphylaxis models in mice, ${ }^{20}$ we assessed the effect of neutrophil depletion using anti-Ly6G antibodies in WT and $\mathrm{Kit}^{W-s h / W-s h}$ mice in this PIA model. We first confirmed that anti-Ly6G injections markedly depleted blood neutrophils (Fig 1, $B$ and $C$ ). Treatment with anti-Ly6G antibodies increased the percentage of blood monocytes without significantly affecting levels of blood eosinophils or basophils (see Fig E2 in the Online Repository). Neutrophil depletion had no significant effect on PN-induced hypothermia in WT mice (Fig 1, D) but significantly reduced the 'late phase' hypothermia (with no significant effect on the immediate hypothermia) in $\mathrm{Kit}^{W-s h / W-s h}$ mice (Fig 1,E). Our results support the conclusion that the neutrophilia in $\mathrm{Kit}^{W-s h / W-s h}$ mice can contribute to the development of their 'late phase' hypothermia response in this PIA model.

\section{Diphtheria toxin-mediated ablation of connective tissue type MCs reduces PIA in Mcpt5- Cre; iDTR ${ }^{+}$mice}

We then attempted to confirm a role for MCs in this PIA model using inducible c-kitindependent MC-deficient Mcpt5-Cre; iDTR ${ }^{+}$mice which express the diphtheria toxin (DT) receptor (DTR) in connective tissue type MCs (CTMCs) but not mucosal MCs (MMCs). ${ }^{31}$ Mice were treated with DT once a week starting at the first sensitization with PN. As expected, when we assessed MC populations in mice killed at the end of the experiment, we found that treatment with DT had depleted MCs in the peritoneal cavity, skin, and forestomach (CTMCs) in Mcpt5-Cre ${ }^{+}$; DTR $^{+}\left(\mathrm{Cre}^{+}\right)$mice but not in $\mathrm{Mcpt5}^{-\mathrm{Cre}^{-}}$; iDTR $^{+}$ $\left(\mathrm{Cre}^{-}\right)$mice and had had no effect on numbers of MMCs in the glandular stomach (Fig 2, A, $B$ and $C$ ). Moreover, we found that DT treatment had no detectable effect on levels of blood 
basophils, neutrophils, eosinophils, or monocytes, as measured $1 \mathrm{~h}$ before PN challenge (see Fig E3 in the Online Repository), and that PN-sensitized $\mathrm{Cre}^{-}$and $\mathrm{Cre}^{+}$mice developed similar serum levels of PN-specific IgE and $\mathrm{IgG}_{1}$ antibodies (see Fig E4 in the Online Repository). Treatment with DT significantly reduced but did not abrogate $\mathrm{PN}$-induced hypothermia in PN-sensitized $\mathrm{Cre}^{+}$mice as compared to $\mathrm{Cre}^{-}$mice (Fig 2, D). These results demonstrate that selective depletion of CTMCs in a non-c-kit mutant mouse strain can significantly reduce hypothermia in this PIA model.

\section{Depletion of basophils reduces PIA}

We next investigated the role of basophils in this PIA model. Treatment of PN-sensitized mice with the basophil-depleting antibody $\mathrm{Ba} 103^{36} 2$ days before $\mathrm{PN}$ challenge reduced but did not fully eliminate $\mathrm{PN}$-induced hypothermia and death as compared to treatment with an isotype control antibody (Fig 3, $A$ ). We confirmed that Ba103 treatment depleted blood basophils (Fig 3, $B$ and $C$ ) without significantly affecting numbers of peritoneal MCs (Fig 3, $D$ ) or levels of blood neutrophils, eosinophils and monocytes (see Fig E5 in the Online Repository).

Because we observed an unusually high mortality rate in the isotype control antibody-treated group $(\sim 57 \%)$ (Fig 3, A) and Ba103 was previously reported also to react with $\mathrm{MCs}^{35}, 36$, we decided to test the PIA model using $M c p t 8^{D T R}$ mice, which express DTR only in basophils and in which basophils can be selectively depleted after a single i.p. injection of $\mathrm{DT}^{39}$. Treatment with DT 2 days before PN challenge reduced but did not fully eliminate PN-induced hypothermia in $M c p t \delta^{D T R /+}\left(\mathrm{DTR}^{+}\right)$mice as compared to $M c p t 8^{+/+}\left(\mathrm{DTR}^{-}\right)$ mice (Fig 4, $A$ ). We confirmed that DT injection depleted blood basophils in PN-sensitized $\mathrm{DTR}^{+}$mice (Fig 4, $B$ and $C$ ), as compared to $\mathrm{DTR}^{-}$mice, without significantly affecting numbers of peritoneal MCs (Fig 4,D) or levels of blood neutrophils, eosinophils and monocytes (see Fig E6 in the Online Repository).

The simplest interpretation of our results is that both basophil-dependent and basophilindependent pathways can contribute to hypothermia in this PIA model.

\section{Reduced but significant PIA in MC- and basophil-deficient Cpa3-Cre; $\mathrm{Mcl-1}{ }^{\mathrm{fl} / f \mathrm{fl}}$ mice}

Because we observed that significant hypothermia can still develop in mice with markedly reduced numbers of MCs (Fig 1 and 2) or basophils (Fig 3 and 4), we decided to assess PIA in $\mathrm{Cpa3}_{-\mathrm{Cre}}{ }^{+}$; $\mathrm{Mcl}-1^{\mathrm{fl} / \mathrm{fl}}$ mice which are severely deficient in MCs and also have a marked deficiency in basophils under steady-state conditions. ${ }^{33}$ PN-sensitized MC- and basophildeficient $\mathrm{Cpa3}-\mathrm{Cre} \mathrm{C}^{+}$: Mcl-1 $1^{\mathrm{fl} / \mathrm{fl}}$ mice and $\mathrm{Cpa3}-\mathrm{Cre}^{+} ; \mathrm{Mcl}^{+1^{++}}$(control) mice developed similar serum levels of PN-specific $\mathrm{IgE}$ and $\mathrm{IgG}_{1}$ antibodies (see Fig E7 in the Online Repository). We found that PN-induced hypothermia was significantly reduced but not fully

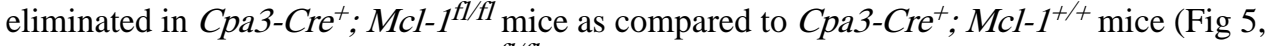
A). Importantly, $\mathrm{Cpa3}-\mathrm{Cr} \mathrm{C}^{+}$; $\mathrm{Mcl}-\mathrm{I}^{\mathrm{fl} / \mathrm{fl}}$ mice remained deficient in both MCs (Fig 5, B, C and $D$ ) and basophils (Fig 5, $E$ and $F$ ) after repeated sensitizations with peanut and peanut challenge. Compared to levels in control $\mathrm{Cpa3}_{-} \mathrm{Cre}^{+} ; \mathrm{Mcl}^{-1^{+/+}}$mice which had been mocksensitized only with cholera toxin and then challenged with PN, elevated levels of histamine were detected 20 min after PN challenge in the plasma and peritoneal cavity of PN-

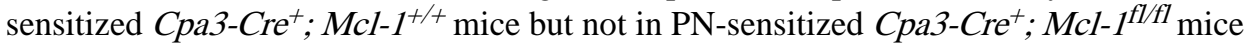
(Fig 5, $G$ and $H$ ). By contrast, we found elevated levels of PAF in plasma and spleen samples at 20 min after PN challenge in PN-sensitized $C p a 3-C r e^{+}$; Mcl- $\left.\right|^{f l / f l}$ mice, as well as

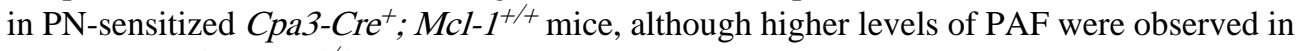

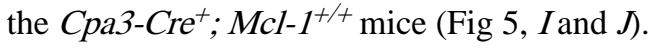


Taken together, our results support the conclusion that both MCs and basophils can contribute to this PIA model but that significant PN-induced hypothermia can still develop in mice markedly deficient in both cell types, perhaps reflecting, at least in part, PN-induced production of PAF in MC- and basophil-deficient mice.

\section{DISCUSSION}

Several studies using c-kit mutant $K i t^{W / W-V}$ and $K i t^{W-s h / W-s h}$ MC-deficient mice have suggested that MCs can significantly contribute to PIA. ${ }^{21,22,41}$ In this report, we confirmed these findings by showing that $K i t^{W-s h / W-s h}$ mice developed reduced immediate hypothermia in this PIA model. However, we found that $K i t^{W-s h / W-s h}$ mice also exhibited a previously unreported late drop in body temperature that occurred between 3 and $6 \mathrm{~h}$ after peanut challenge, after the hypothermia induced acutely by peanut challenge had fully resolved. Notably, we were able to essentially eliminate this second phase of peanut-induced hypothermia by using anti-Ly6G antibodies to markedly reduce neutrophils in the $K i t^{W-s h / W-s h}$ mice before challenging them with peanut. Such neutrophil ablation had no detectable effect on the hypothermia response induced by peanut challenge in WT mice. These results indicate that neutrophils may contribute to the PIA response in $\mathrm{Kit}^{\mathrm{W}-\mathrm{sh} / \mathrm{W} \text {-sh }}$ mice, which are known to have a neutrophilia at baseline, ${ }^{27-29}$ but that any contributions of neutrophils are redundant with those of other effector cells in the corresponding WT mice.

Because of the many phenotypic abnormalities of c-kit mutant mice, we recommend investigating the roles of MCs in biological responses by attempting to confirm results using two different types of MC-deficient mice, such as c-kit mutant mice and one of the newly described non-c-kit mutant MC-deficient strains. ${ }^{25}$ In the present study, we showed that the selective reduction in the numbers of CTMCs induced by DT injection in Mcpt5-Cre; iDTR mice significantly reduced (but did not eliminate) the hypothermia these mice developed in this PIA model. The residual hypothermia response to peanut observed in the Mcpt5-Cre; iDTR mice might have reflected contributions of MMCs (or other MC populations not depleted by DT treatment in these mice), basophils, and/or other effector cell types.

Several lines of evidence suggest that basophils, in addition to MCs, can play a significant role in food allergy and food allergy-induced anaphylaxis. For example, changes in human basophil cell surface markers, such as CD203c or CD63, whose levels are elevated upon immunological activation of basophils, can be used to diagnose or confirm sensitization to peanut and other food allergens and to monitor the effects of efforts to treat these conditions with immunotherapy. ${ }^{4,-48}$ However, in humans, it is difficult to ascertain how important a contribution basophil activation makes to the pathology of food-allergy-induced anaphylaxis.

Even in mice, the role of basophils in anaphylaxis is controversial. Tsujimura and collaborators first showed that depletion of basophils via injection of the basophil-depleting antibody Ba103 rescued mice from $\mathrm{IgG}_{1}$-mediated but not IgE-mediated PSA and also rescued c-kit mutant MC-deficient mice (but not WT mice) from active anaphylaxis. ${ }^{18}$ However, Ohnmacht et al. subsequently observed no involvement of basophils in $\mathrm{IgG}_{1^{-}}$ mediated PSA and active anaphylaxis using Mcpt8-Cre mice in which Cre-mediated cytotoxicity leads to more than $90 \%$ depletion of basophils. ${ }^{49}$

In our study, we observed that depletion of basophils using Ba103 resulted in a partial but significant reduction of hypothermia following peanut challenge. These results contrast with a previous report showing no significant effect of Ba103 in hypothermia in a PIA model. ${ }^{41}$ However, in that prior report, Smit and collaborators challenged the mice with five-times less peanut extract than we used, which may have resulted in a more pronounced 
dependency of the response on IgE and MCs. ${ }^{50,51}$ The high dependence of the model tested by Smit et al. on MCs also is suggested by the complete protection observed in $\mathrm{Kit}^{W-s h / W-s h}$ mice in their model $;{ }^{41}$ by contrast, in our model, small but significant hypothermia responses were induced by peanut challenge in $\mathrm{Kit}^{W-s h / W-s h}$ mice. Arias et al also observed no significant effect of basophil depletion using Ba103 on the hypothermia in another PIA model. ${ }^{22}$ However, that group reported that treatment with Ba103 protected mice from death in their model, suggesting a critical role for basophils in the development of that biologically important endpoint. ${ }^{22}$

Because we observed an unusually high mortality rate in the isotype control antibody-treated group ( $57 \%$ vs $0-16 \%$ in all other experiments), and Ba103 was previously reported also to react with $\mathrm{MCs},{ }^{35,36}$ we decided to attempt to confirm our results using $M c p t 8^{D T R}$ mice in which basophils can be selectively depleted by a single injection of DT. ${ }^{39}$ Basophil deficient DT-treated $M c p t \delta^{D T R /+}$ mice developed significantly reduced hypothermia as compared to DT-treated $M c p t 8^{+/+}$mice, providing additional evidence that basophils contribute significantly to anaphylaxis in this PIA model.

Beside MCs and basophils, other effector cells such as neutrophils ${ }^{20}$ and macrophages ${ }^{22,41,52}$ have been shown to contribute to certain models of IgG-mediated anaphylaxis in mice. We used $C p a 3-C r e^{+} ; \mathrm{Mcl}-1^{f l / f l}$ mice, which are severely deficient in MCs and also have a marked deficiency in basophils under steady-state conditions, ${ }^{33}$ to assess whether other effector cells might contribute to the hypothermia in this PIA model. We previously reported that $C \mathrm{~Pa} 3-\mathrm{Cre}^{+} ; \mathrm{Mcl}-\mathrm{I}^{\mathrm{fl} / \mathrm{fl}}$ mice developed markedly attenuated MCdependent IgE-mediated PCA and PSA reactions ${ }^{33,53,54}$ and also essentially fail to express a basophil-dependent IgE-mediated chronic allergic skin reaction (CAI). ${ }^{33}, 55$ In this report, we found that $\mathrm{Cpa3}-\mathrm{Cre}^{+} ; \mathrm{Mcl}-\mathrm{I}^{\mathrm{fl} / \mathrm{fl}}$ mice developed reduced but still significant hypothermia in our PIA model. We found no elevation in histamine levels after challenge with peanut in peanut-sensitized $\mathrm{Cpa3}-\mathrm{Cre}^{+} ; \mathrm{Mcl}-\mathrm{I}^{\mathrm{fl} / \mathrm{fl}}$ mice, indicating that MCs and/or basophils are the main source of histamine in this model. We also observed reduced levels of PAF after peanut challenge in peanut-sensitized $\mathrm{Cpa3}_{-} \mathrm{Cre}^{+} ; \mathrm{Mcl}^{-1}{ }^{\mathrm{fl} / \mathrm{fl}}$ mice, as compared

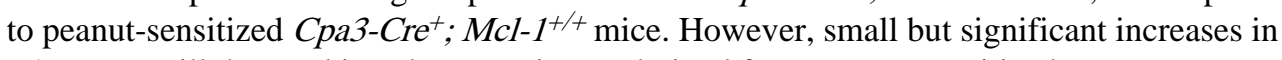
$\mathrm{PAF}$ were still detected in spleen specimens derived from peanut-sensitized, peanut challenged $\mathrm{Cpa3}-\mathrm{Cre}^{+} ; \mathrm{Mcl}-1^{\mathrm{fl} / f l}$ mice. Altogether, these results suggest that either the small

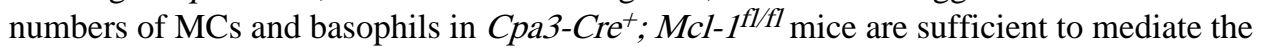
weak hypothermia response and small increases in PAF observed in these mice in this model, or that other effector cells, such as macrophages and/or neutrophils, can do so. These results also strongly suggest that the weak hypothermia observed in peanut-sensitized, peanut challenged $\mathrm{Cpa3}-\mathrm{Cr} \mathrm{C}^{+} ; \mathrm{Mcl}-1^{\mathrm{fl} / \mathrm{fl}}$ mice is independent of histamine.

Because anaphylaxis can occur after ingestion of low doses of allergen in food allergic patients, we also assessed the respective contribution of MCs versus basophils in a more moderate model of PIA (using two-fold less adjuvant during the sensitization phase and twofold less peanut for the challenge). As reported previously ${ }^{21}, \mathrm{Kit}^{W-s h / W-s h}$ mice were essentially protected from the immediate hypothermia induced by challenge with peanut in this moderate PIA model (see Fig E8 in the Online Repository). However, these mice still developed a late drop in body temperature, occurring 3 to $6 \mathrm{~h}$ post challenge with peanut as in the more severe model (see Fig E8 in the Online Repository).

We obtained additional evidence for an important contribution of MCs in the acute response to peanut in this model by showing that engraftment of $\mathrm{Kit}^{W-s h / W-s h}$ mice with bone marrow-derived cultured MCs (BMCMCs $\rightarrow K i t^{W-s h / W-s h}$ mice) partially restored the immediate hypothermia but had no significant effect on the late phase drop in body temperature in this model (see Fig E8 in the Online Repository). We think that technical 
limitations of such systemic MC engraftment experiments may have contributed to the 'intermediate' temperature response seen in MC-engrafted $K i{ }^{W-s h} / W$-sh mice, as compared to WT or MC-deficient Kit ${ }^{W-s h / W-s h}$ mice. Specifically, WT mice and $\mathrm{BMCMCs} \rightarrow K i t^{W-s h / W-s}$ mice had similar levels of MCs in the peritoneal cavity, mesenteric windows, lungs and stomach, and BMCMCs $\rightarrow K i t^{W-s h / W-s h}$ mice higher than WT numbers of MCs in the spleen, but the MC-engrafted $\mathrm{Kit}^{\mathrm{W}-\mathrm{sh} / \mathrm{W} \text {-sh }}$ mice had no detectable MCs in the skin, thus eliminating skin MCs as a potential source of mediators in such mice (see Fig E8 in the Online Repository). In sharp contrast with the observed important role for MCs in this moderate PIA model, depletion of basophils (either by use of the basophil-depleting antibody Ba103 or by injection of DT to deplete basophils in $M c p t 8^{D T R /+}$ mice) did not significantly diminish the hypothermia induced by challenge with peanut in this model (see Fig E9 in the Online Repository).

In conclusion, we demonstrate that MCs, rather than basophils, contribute significantly to anaphylaxis in response to challenge with low doses of peanut in peanut-sensitized mice in a moderately severe model of PIA. By contrast, selective and inducible ablation of either MCs or basophils in non-c-kit mutant mice is sufficient to reduce significantly the hypothermia which develops in a more severe PIA model. However, in this severe model of PIA, significant hypothermia can still develop in the virtual absence of MCs or basophils, and in mice that are markedly deficient in both effector cell types. Taken together, these results suggest that effector cells beside MCs and basophils also can contribute to anaphylaxis in this mouse model. Although care must be taken when attempting to extrapolate findings from animal models of a disease to their human counterparts, our results suggest that targeted inhibition of MCs and basophils could have significant therapeutic benefit in peanut allergies and anaphylaxis, but that other effector elements may also contribute to the pathology in such settings.

\title{
Supplementary Material
}

Refer to Web version on PubMed Central for supplementary material.

\section{Acknowledgments}

\author{
We thank Mariola Liebersbach for her help with mouse breeding, Chen Liu for processing slides for histological \\ analysis, and Drs. Takao Shimizu and Masaki Yamada of the University of Tokyo for help with the measurements \\ of PAF. \\ Declaration of funding sources: \\ L.L.R. is the recipient of fellowships from the French "Fondation pour la Recherche Médicale FRM" and the \\ Stanford Pediatric Research Fund of the Lucile Packard Foundation for Children's Health and the Stanford CTSA \\ (National Institutes of Health grant UL1 RR025744); T.M. is supported by a fellowship from the Belgium \\ American Educational Foundation and a Marie Curie International outgoing Fellowship for Career Development: \\ 299954; K.H. acknowledges support from the German Research Council (DFG; CRC/SFB832, project A14); S.J.G. \\ acknowledges support from National Institutes of Health grants AI023990, CA072074 and AI070813.
}

\section{Abbreviations used}

$\begin{array}{ll}\text { Cpa3 } & \text { Carboxypeptidase A3 } \\ \text { DT } & \text { Diphtheria toxin } \\ \text { MC } & \text { Mast cell } \\ \text { Mcpt } & \text { Mast cell protease } \\ \text { PIA } & \text { Peanut-induced anaphylaxis }\end{array}$


$\begin{array}{ll}\text { PN } & \text { Peanut } \\ \text { WT } & \text { Wild-type }\end{array}$

\section{REFERENCES}

1. Sicherer SH, Sampson HA. Food allergy: recent advances in pathophysiology and treatment. Annu Rev Med. 2009; 60:261-277. [PubMed: 18729729]

2. Bock SA, Munoz-Furlong A, Sampson HA. Fatalities due to anaphylactic reactions to foods. J Allergy Clin Immunol. 2001; 107:191-193. [PubMed: 11150011]

3. Bock SA, Munoz-Furlong A, Sampson HA. Further fatalities caused by anaphylactic reactions to food, 2001-2006. J Allergy Clin Immunol. 2007; 119:1016-1018. [PubMed: 17306354]

4. Jones SM, Pons L, Roberts JL, Scurlock AM, Perry TT, Kulis M, et al. Clinical efficacy and immune regulation with peanut oral immunotherapy. J Allergy Clin Immunol. 2009; 124:292-300. e1-97. [PubMed: 19577283]

5. Sicherer SH, Munoz-Furlong A, Sampson HA. Prevalence of peanut and tree nut allergy in the United States determined by means of a random digit dial telephone survey: a 5-year follow-up study. J Allergy Clin Immunol. 2003; 112:1203-1207. [PubMed: 14657884]

6. Galli, SJ.; Metcalfe, DD.; Arber, DA.; Dvorak, AM. Basophils and mast cells and their disorders. In: Lichtman, MA.; Beutler, E.; Kipps, TJ.; Seligsohn, U.; Kaushansky, K.; Prchal, JT., editors. Williams Hematology. New York: McGraw-Hill Medical; 2005. p. 879-897.

7. Gibbs BF. Human basophils as effectors and immunomodulators of allergic inflammation and innate immunity. Clin Exp Med. 2005; 5:43-49. [PubMed: 16096852]

8. Brown JM, Wilson TM, Metcalfe DD. The mast cell and allergic diseases: role in pathogenesis and implications for therapy. Clin Exp Allergy. 2008; 38:4-18. [PubMed: 18031566]

9. Min B. Basophils: what they 'can do' versus what they 'actually do'. Nat Immunol. 2008; 9:13331339. [PubMed: 19008933]

10. Karasuyama H, Mukai K, Tsujimura Y, Obata K. Newly discovered roles for basophils: a neglected minority gains new respect. Nat Rev Immunol. 2009; 9:9-13. [PubMed: 19039320]

11. Sullivan BM, Locksley RM. Basophils: a nonredundant contributor to host immunity. Immunity. 2009; 30:12-20. [PubMed: 19144314]

12. Galli SJ, Tsai M. Mast cells in allergy and infection: versatile effector and regulatory cells in innate and adaptive immunity. Eur J Immunol. 2010; 40:1843-1851. [PubMed: 20583030]

13. Bochner BS, Lichtenstein LM. Anaphylaxis. N Engl J Med. 1991; 324:1785-1790. [PubMed: 1789822]

14. Marone G, Galli SJ, Kitamura Y. Probing the roles of mast cells and basophils in natural and acquired immunity, physiology and disease. Trends Immunol. 2002; 23:425-427. [PubMed: 12200056]

15. Galli SJ. Pathogenesis and management of anaphylaxis: current status and future challenges. J Allergy Clin Immunol. 2005; 115:571-574. [PubMed: 15753906]

16. Dombrowicz D, Flamand V, Miyajima I, Ravetch JV, Galli SJ, Kinet JP. Absence of Fc epsilonRI alpha chain results in upregulation of Fc gammaRIII-dependent mast cell degranulation and anaphylaxis. Evidence of competition between Fc epsilonRI and Fc gammaRIII for limiting amounts of FcR beta and gamma chains. J Clin Invest. 1997; 99:915-925. [PubMed: 9062349]

17. Miyajima I, Dombrowicz D, Martin TR, Ravetch JV, Kinet JP, Galli SJ. Systemic anaphylaxis in the mouse can be mediated largely through IgG1 and Fc gammaRIII. Assessment of the cardiopulmonary changes, mast cell degranulation, and death associated with active or IgE- or IgG1-dependent passive anaphylaxis. J Clin Invest. 1997; 99:901-914. [PubMed: 9062348]

18. Tsujimura Y, Obata K, Mukai K, Shindou H, Yoshida M, Nishikado H, et al. Basophils play a pivotal role in immunoglobulin-G-mediated but not immunoglobulin-E-mediated systemic anaphylaxis. Immunity. 2008; 28:581-589. [PubMed: 18342553]

19. Finkelman FD. Anaphylaxis: lessons from mouse models. J Allergy Clin Immunol. 2007; 120:506-515. quiz 16-7. [PubMed: 17765751] 
20. Jonsson F, Mancardi DA, Kita Y, Karasuyama H, Iannascoli B, Van Rooijen N, et al. Mouse and human neutrophils induce anaphylaxis. J Clin Invest. 2011; 121:1484-1496. [PubMed: 21436586]

21. Sun J, Arias K, Alvarez D, Fattouh R, Walker T, Goncharova S, et al. Impact of CD40 ligand, B cells, and mast cells in peanut-induced anaphylactic responses. J Immunol. 2007; 179:6696-6703. [PubMed: 17982059]

22. Arias K, Chu DK, Flader K, Botelho F, Walker T, Arias N, et al. Distinct immune effector pathways contribute to the full expression of peanut-induced anaphylactic reactions in mice. $\mathrm{J}$ Allergy Clin Immunol. 2011; 127:1552-1561. e1. [PubMed: 21624619]

23. Rodewald HR, Feyerabend TB. Widespread immunological functions of mast cells: fact or fiction? Immunity. 2012; 37:13-24. [PubMed: 22840840]

24. Brown MA, Hatfield JK. Mast Cells are Important Modifiers of Autoimmune Disease: With so Much Evidence, Why is There Still Controversy? Front Immunol. 2012; 3:147. [PubMed: 22701454]

25. Reber LL, Marichal T, Galli SJ. New models for analyzing mast cell functions in vivo. Trends Immunol. 2012; 33:613-625. [PubMed: 23127755]

26. Chervenick PA, Boggs DR. Decreased neutrophils and megakaryocytes in anemic mice of genotype $W / W^{V}$. J Cell Physiol. 1969; 73:25-30. [PubMed: 5765776]

27. Zhou JS, Xing W, Friend DS, Austen KF, Katz HR. Mast cell deficiency in $\mathrm{Kit}^{\left({ }^{W-s h}\right)}$ mice does not impair antibody-mediated arthritis. J Exp Med. 2007; 204:2797-2802. [PubMed: 17998392]

28. Nigrovic PA, Gray DH, Jones T, Hallgren J, Kuo FC, Chaletzky B, et al. Genetic inversion in mast cell-deficient (Wsh) mice interrupts corin and manifests as hematopoietic and cardiac aberrancy. Am J Pathol. 2008; 173:1693-1701. [PubMed: 18988802]

29. Piliponsky AM, Chen CC, Grimbaldeston MA, Burns-Guydish SM, Hardy J, Kalesnikoff J, et al. Mast cell-derived TNF can exacerbate mortality during severe bacterial infections in C57BL/6KitW-sh/W-sh mice. Am J Pathol. 2010; 176:926-938. [PubMed: 20035049]

30. Otsuka A, Kubo M, Honda T, Egawa G, Nakajima S, Tanizaki H, et al. Requirement of interaction between mast cells and skin dendritic cells to establish contact hypersensitivity. PLoS One. 2011; 6:e25538. [PubMed: 21980488]

31. Dudeck A, Dudeck J, Scholten J, Petzold A, Surianarayanan S, Kohler A, et al. Mast cells are key promoters of contact allergy that mediate the adjuvant effects of haptens. Immunity. 2011; 34:973-984. [PubMed: 21703544]

32. Feyerabend TB, Weiser A, Tietz A, Stassen M, Harris N, Kopf M, et al. Cre-mediated cell ablation contests mast cell contribution in models of antibody- and T cell-mediated autoimmunity. Immunity. 2011; 35:832-844. [PubMed: 22101159]

33. Lilla JN, Chen CC, Mukai K, BenBarak MJ, Franco CB, Kalesnikoff J, et al. Reduced mast cell and basophil numbers and function in Cpa3-Cre; Mcl-1fl/fl mice. Blood. 2011; 118:6930-6938. [PubMed: 22001390]

34. Scholten J, Hartmann K, Gerbaulet A, Krieg T, Muller W, Testa G, et al. Mast cell-specific Cre/ loxP-mediated recombination in vivo. Transgenic Res. 2008; 17:307-315. [PubMed: 17972156]

35. Kojima T, Obata K, Mukai K, Sato S, Takai T, Minegishi Y, et al. Mast cells and basophils are selectively activated in vitro and in vivo through CD200R3 in an IgE-independent manner. J Immunol. 2007; 179:7093-7100. [PubMed: 17982101]

36. Obata K, Mukai K, Tsujimura Y, Ishiwata K, Kawano Y, Minegishi Y, et al. Basophils are essential initiators of a novel type of chronic allergic inflammation. Blood. 2007; 110:913-920. [PubMed: 17409268]

37. Denzel A, Maus UA, Rodriguez Gomez M, Moll C, Niedermeier M, Winter C, et al. Basophils enhance immunological memory responses. Nat Immunol. 2008; 9:733-742. [PubMed: 18516038]

38. Sokol CL, Barton GM, Farr AG, Medzhitov R. A mechanism for the initiation of allergen-induced T helper type 2 responses. Nat Immunol. 2008; 9:310-318. [PubMed: 18300366]

39. Wada T, Ishiwata K, Koseki H, Ishikura T, Ugajin T, Ohnuma N, et al. Selective ablation of basophils in mice reveals their nonredundant role in acquired immunity against ticks. J Clin Invest. 2010; 120:2867-2875. [PubMed: 20664169]

40. Daley JM, Thomay AA, Connolly MD, Reichner JS, Albina JE. Use of Ly6G-specific monoclonal antibody to deplete neutrophils in mice. J Leukoc Biol. 2008; 83:64-70. [PubMed: 17884993] 
41. Smit JJ, Willemsen K, Hassing I, Fiechter D, Storm G, van Bloois L, et al. Contribution of classic and alternative effector pathways in peanut-induced anaphylactic responses. PLoS One. 2011; 6:e28917. [PubMed: 22194949]

42. Ocmant A, Mulier S, Hanssens L, Goldman M, Casimir G, Mascart F, et al. Basophil activation tests for the diagnosis of food allergy in children. Clin Exp Allergy. 2009; 39:1234-1245. [PubMed: 19549026]

43. Wanich N, Nowak-Wegrzyn A, Sampson HA, Shreffler WG. Allergen-specific basophil suppression associated with clinical tolerance in patients with milk allergy. J Allergy Clin Immunol. 2009; 123:789-794. e20. [PubMed: 19348919]

44. Gernez Y, Tirouvanziam R, Yu G, Ghosn EE, Reshamwala N, Nguyen T, et al. Basophil CD203c levels are increased at baseline and can be used to monitor omalizumab treatment in subjects with nut allergy. Int Arch Allergy Immunol. 2011; 154:318-327. [PubMed: 20975283]

45. Kim EH, Bird JA, Kulis M, Laubach S, Pons L, Shreffler W, et al. Sublingual immunotherapy for peanut allergy: clinical and immunologic evidence of desensitization. J Allergy Clin Immunol. 2011; 127:640-646. e1. [PubMed: 21281959]

46. Ford LS, Bloom KA, Nowak-Wegrzyn AH, Shreffler WG, Masilamani M, Sampson HA. Basophil reactivity, wheal size, and immunoglobulin levels distinguish degrees of cow's milk tolerance. $\mathrm{J}$ Allergy Clin Immunol. 2012

47. Gernez Y, Tirouvanziam R, Reshamwala N, Yu G, Weldon BC, Galli SJ, et al. Modulation of mTOR effector phosphoproteins in blood basophils from allergic patients. J Clin Immunol. 2012; 32:565-573. [PubMed: 22350221]

48. Keet CA, Frischmeyer-Guerrerio PA, Thyagarajan A, Schroeder JT, Hamilton RG, Boden S, et al. The safety and efficacy of sublingual and oral immunotherapy for milk allergy. J Allergy Clin Immunol. 2012; 129:448-455. e1-5. [PubMed: 22130425]

49. Ohnmacht C, Schwartz C, Panzer M, Schiedewitz I, Naumann R, Voehringer D. Basophils orchestrate chronic allergic dermatitis and protective immunity against helminths. Immunity. 2010; 33:364-374. [PubMed: 20817571]

50. Finkelman FD, Rothenberg ME, Brandt EB, Morris SC, Strait RT. Molecular mechanisms of anaphylaxis: lessons from studies with murine models. J Allergy Clin Immunol. 2005; 115:449457. quiz 58. [PubMed: 15753886]

51. Strait RT, Morris SC, Finkelman FD. IgG-blocking antibodies inhibit IgE-mediated anaphylaxis in vivo through both antigen interception and Fc gamma RIIb cross-linking. J Clin Invest. 2006; 116:833-841. [PubMed: 16498503]

52. Strait RT, Morris SC, Yang M, Qu XW, Finkelman FD. Pathways of anaphylaxis in the mouse. J Allergy Clin Immunol. 2002; 109:658-668. [PubMed: 11941316]

53. Wershil BK, Mekori YA, Murakami T, Galli SJ. 125I-fibrin deposition in IgE-dependent immediate hypersensitivity reactions in mouse skin. Demonstration of the role of mast cells using genetically mast cell-deficient mice locally reconstituted with cultured mast cells. J Immunol. 1987; 139:2605-2614. [PubMed: 3655368]

54. Martin TR, Ando A, Takeishi T, Katona IM, Drazen JM, Galli SJ. Mast cells contribute to the changes in heart rate, but not hypotension or death, associated with active anaphylaxis in mice. $\mathrm{J}$ Immunol. 1993; 151:367-376. [PubMed: 7686942]

55. Mukai K, Matsuoka K, Taya C, Suzuki H, Yokozeki H, Nishioka K, et al. Basophils play a critical role in the development of IgE-mediated chronic allergic inflammation independently of $\mathrm{T}$ cells and mast cells. Immunity. 2005; 23:191-202. [PubMed: 16111637] 


\section{Key messages}

- Selective and inducible ablation of MCs or basophils can significantly reduce features of a severe model of peanut-induced anaphylaxis (PIA) in non-c-kit mutant mice.

- Reduced, but still significant, PIA develops in the virtual absence of both MCs and basophils in non-c-kit mutant mice.

- The neutrophilia of c-kit mutant MC-deficient $K i t^{W-s h / W-s h}$ mice can influence responses of this strain of mice in this PIA model. 
A

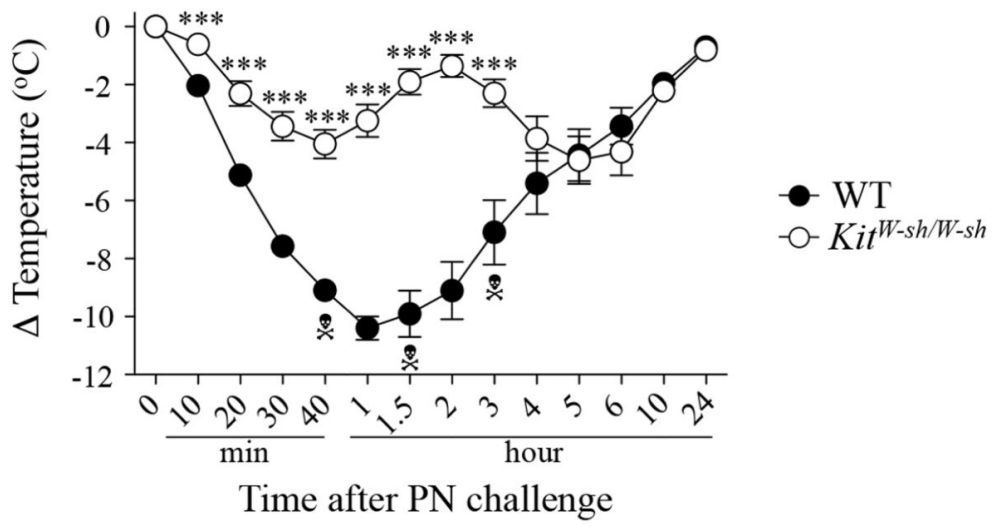

B

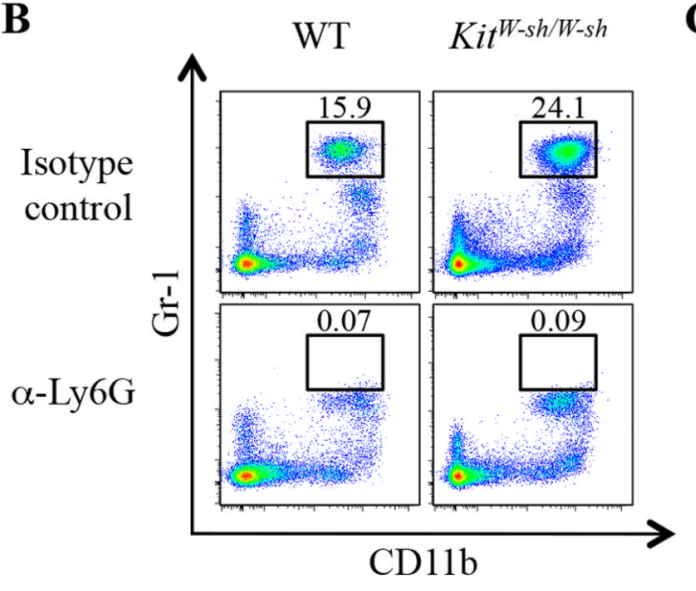

D

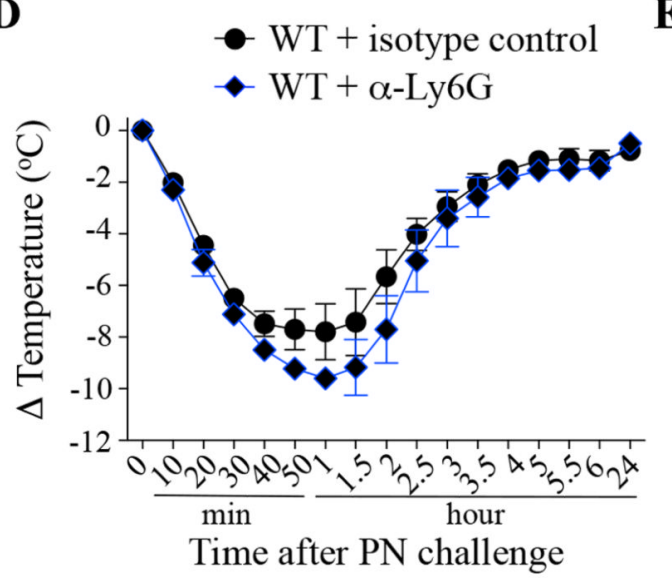

C

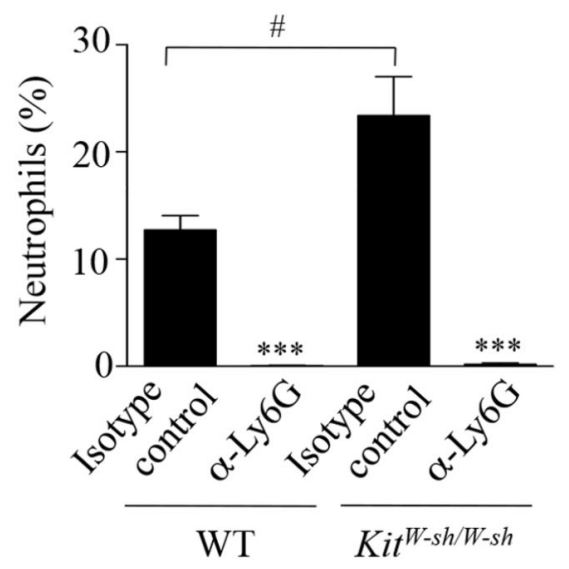

$\mathbf{E}$

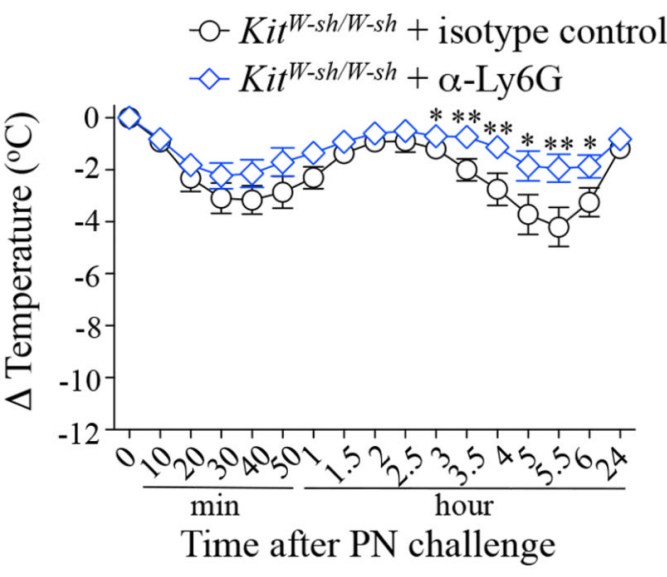

FIG 1. Effect of treatment with anti-Ly6G antibodies on peanut-induced anaphylaxis in WT and $\mathrm{Kit}^{\mathrm{W}-\mathrm{sh} / \mathrm{W} \text {-sh }}$ mice

(A) PN-induced hypothermia in PN-sensitized C57BL/6J (WT; $n=19$ ) and MC-deficient C57BL/6J-Kit ${ }^{W-s h / W-s h}$ mice $\left(K i t^{W-s h / W-s h} ; n=18\right)$. (B-E) PN-sensitized WT ( $\left.n=5\right)$ and MCdeficient $K i t^{W-s h / W-s h}$ mice $(n=12-15)$ were treated i.p. with $500 \mu \mathrm{g}$ of neutrophil-depleting anti-Ly6G (a-Ly6G) or isotype control antibodies $24 \mathrm{~h}$ before the challenge. (B) Representative flow cytometry plots showing blood neutrophils (Siglec-F ${ }^{-}$(not shown); Gr- high $^{\text {hi }}$ CD1 $1 b^{+}$). (C) Percentage of blood neutrophils. (D-E) PN-induced hypothermia in WT mice (D) and $\mathrm{Kit}^{W-s h / W-s h}$ mice $(\mathbf{E})$ treated with an anti-Ly6G antibody (a-Ly6G) or isotype control antibody. Data are mean \pm SEM or mean $+\mathrm{SEM}$; $* * *$ or $* * *=P<0.05,<$ 
0.01 or $<0.001$ vs. corresponding WT group (in A) or isotype control antibody-treated group (in $\mathbf{C}$ and $\mathbf{E}$ ); $\#=P<0.05$ vs. indicated group (in $\mathbf{C}$ ); Each crossbones symbol indicates death of one WT mouse. 
A

C

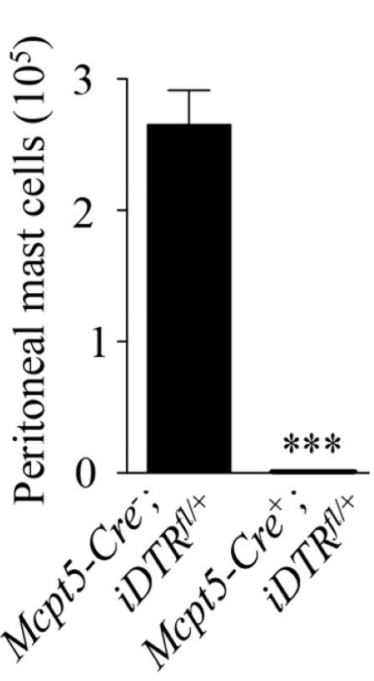

B
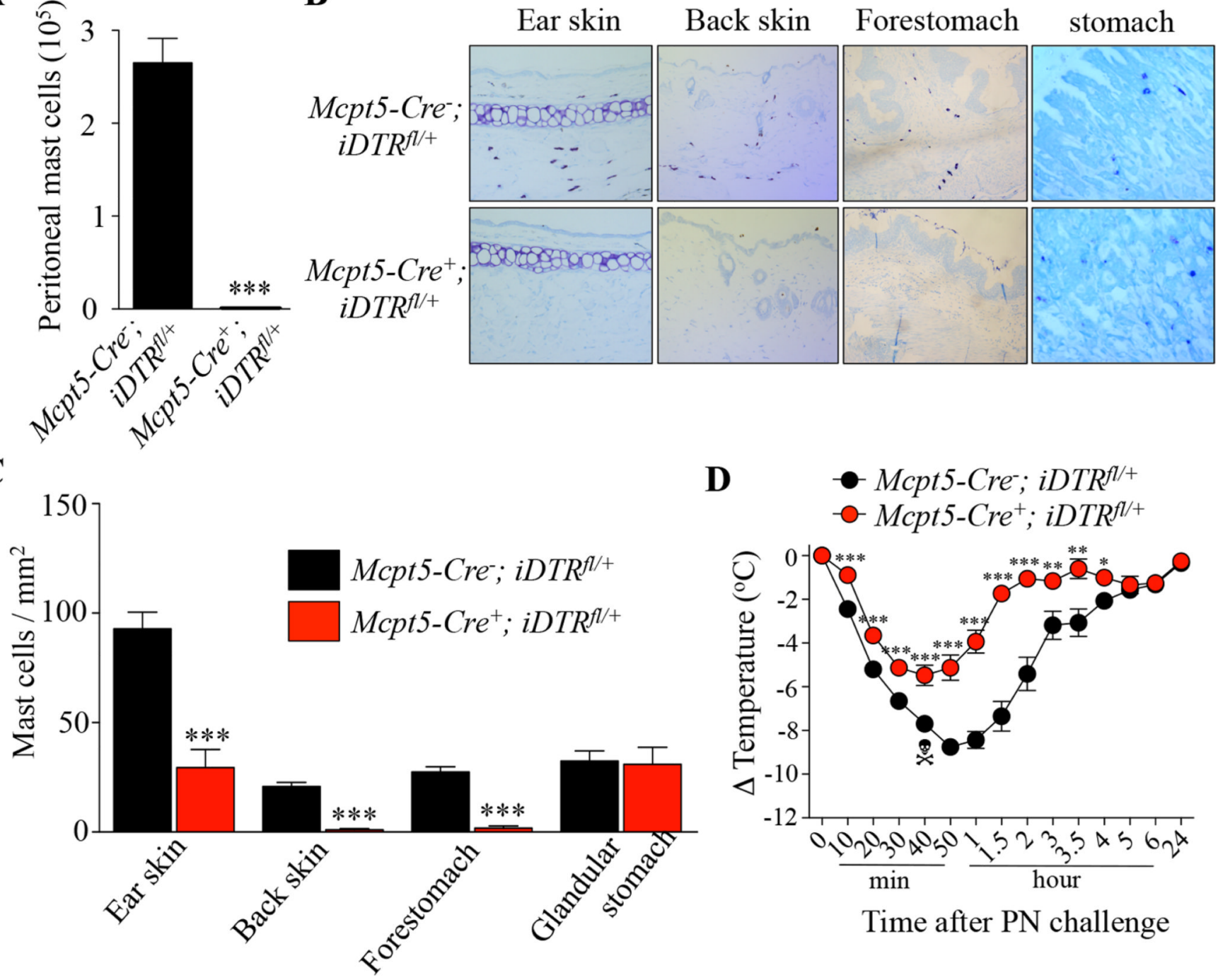

D

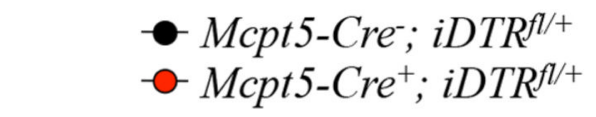

FIG 2. Effect of diphtheria toxin-mediated connective-tissue mast cell depletion on peanutinduced anaphylaxis in Mcpt5-Cre; iDTR mice

(A) Numbers of MCs in the peritoneal lavage fluid from DT-treated $\mathrm{Mcpt5}^{-\mathrm{Cre}^{-}}$; iDTR fl/t mice ( $n=9)$ and Mcpt5-Cre ${ }^{+} ;$iDTR $^{f l / t}$ mice $(n=5)$. (B-C) Toluidine blue staining for MCs (B) and MC numbers (C) in sections of ear skin, back skin, forestomach and glandular stomach in DT-treated Mcpt5-Cre ${ }^{-} ; i$ TR $^{f l /+}$ mice $(n=6-9)$ and $M c p t 5-C r e^{+} ; i D T R^{f l /+}$ mice $(n=5)$. (D) PN-induced hypothermia in DT-treated PN-sensitized Mcpt5-Cre ${ }^{-}$; iDTR ${ }^{f l / t}$ mice $(n=15)$ and $M c p t 5-C r e^{+} ; i_{T R}^{f l / t}$ mice $(n=13)$. Data are mean \pm SEM or mean + SEM; $*$, ** or $* * *=<0.05,0.01$ or 0.001 Vs. corresponding $M c p t 5-C r e^{-} ; i D T R^{f l / t}$ group; Crossbones symbol indicates death of one mouse. 
A

- Isotype control

$-\mathrm{O}$ - Ba103

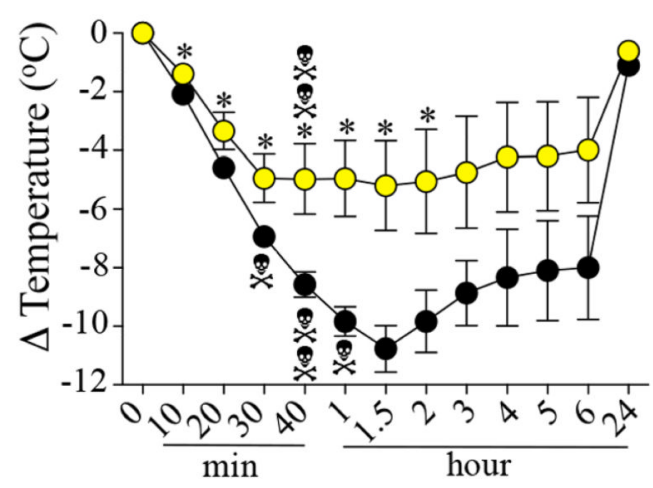

Time after PN challenge
B

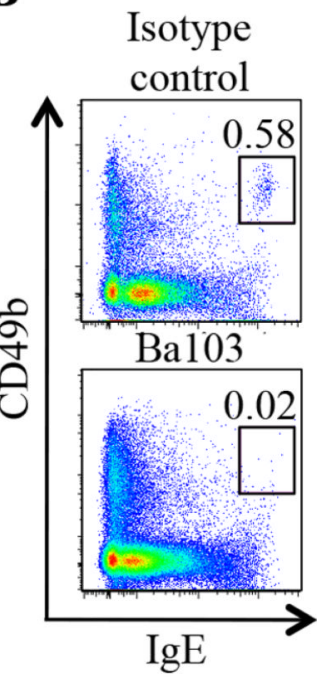

C

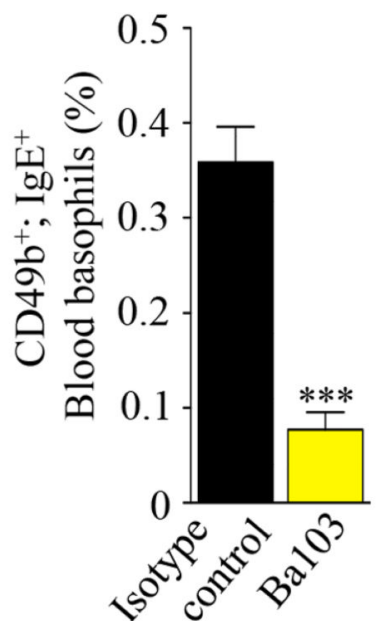

D

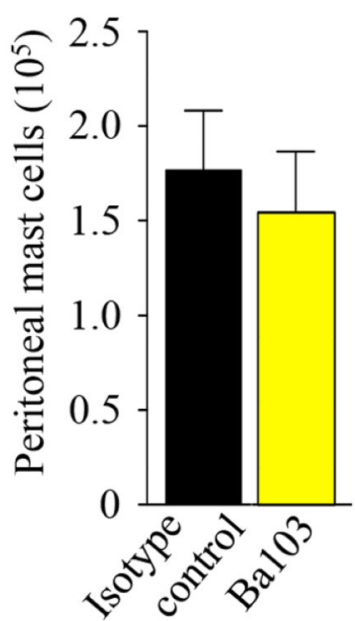

FIG 3. Effect of antibodies-mediated basophil depletion on peanut-induced anaphylaxis PN-sensitized C57BL/6J mice treated i.p. with $50 \mu \mathrm{g}$ of basophil-depleting antibodies Ba103 ( $n=9)$ or isotype control antibodies ( $n=7) 48 \mathrm{~h}$ before PN challenge. (A) PN-induced hypothermia. (B-C) Representative flow cytometry plots (B) and percentage (C) of blood basophils $\left(\mathrm{CD} 4 \mathrm{~b}^{+} ; \mathrm{IgE}^{+}\right.$). (D) Numbers of MCs in the peritoneal lavage fluid. Data are mean \pm SEM or mean + SEM; $*$ or $* * *=P<0.05$ or $<0.001 \mathrm{vs}$. isotype control antibodytreated group; Each crossbones symbol indicates death of one mouse. 
A

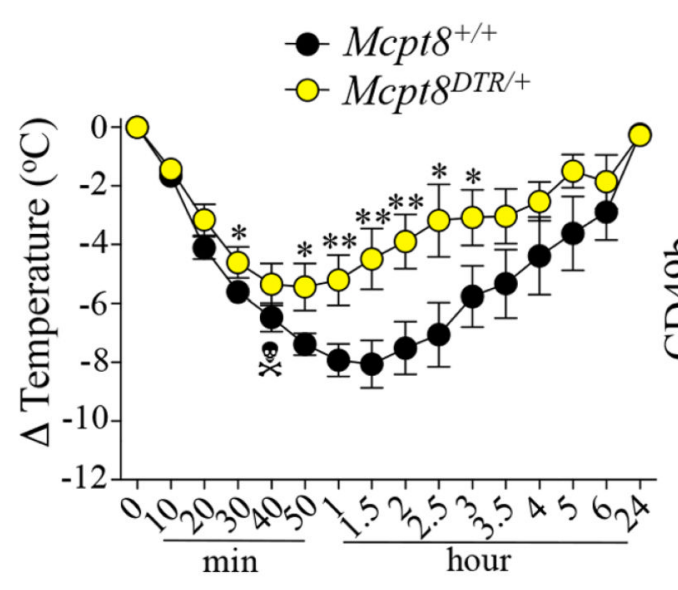

Time after PN challenge
B

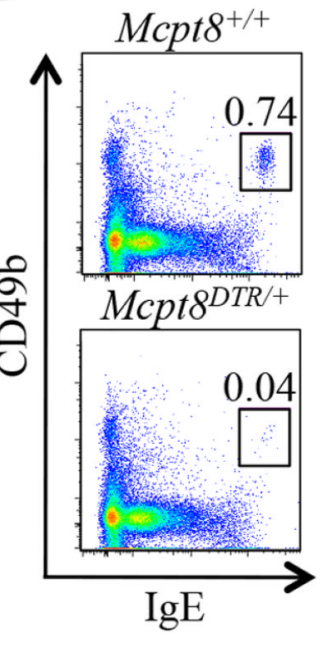

C

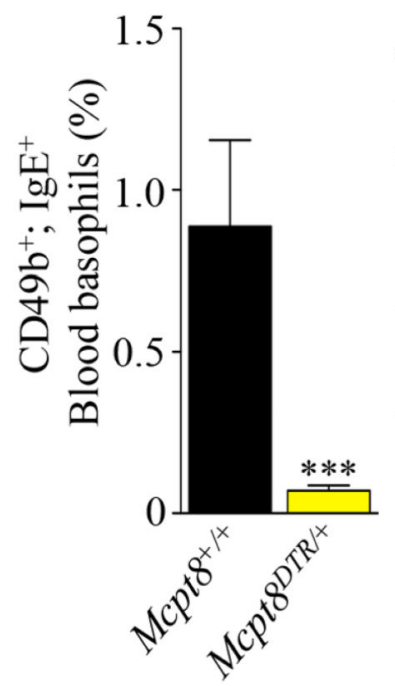

D

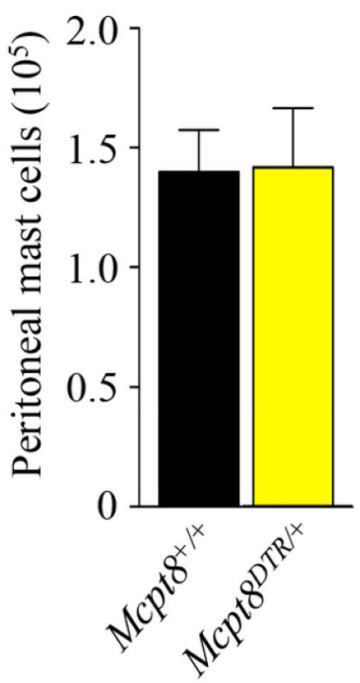

FIG 4. Effect of diphtheria toxin-mediated basophil depletion on peanut-induced anaphylaxis in Mcpt8 ${ }^{\text {DTR }}$ mice

PN-sensitized $\operatorname{Mcpt}^{+/+}(n=10)$ and $\operatorname{Mcpt}^{D T R /+}(n=10)$ mice were treated with DT $48 \mathrm{~h}$ before challenge with PN. (A) PN-induced hypothermia. (B-C) Representative flow cytometry plots $(\mathbf{B})$ and percentage $(\mathbf{C})$ of blood basophils $\left(C D 49 b^{+} ; \operatorname{IgE}^{+}\right)$. (D) Numbers of $\mathrm{MCs}$ in the peritoneal lavage fluid. Data are mean \pm SEM or mean $+\mathrm{SEM} ; * * *$ or $* * *=P$ $<0.05,<0.01$ or $<0.001$ VS. corresponding $\mathrm{Mcpt}^{+/+}$group; Crossbones symbol indicates death of one mouse. 
A

- $\mathrm{Cpa3}_{-\mathrm{Cre}}^{+} ; \mathrm{Mcl}-\mathrm{I}^{+/+}$

- - Cpa3-Cre ${ }^{+}$; Mcl-l $\mathrm{I}^{\mathrm{fl} f \mathrm{l}}$

C

Time after PN challenge

G

H mice
B

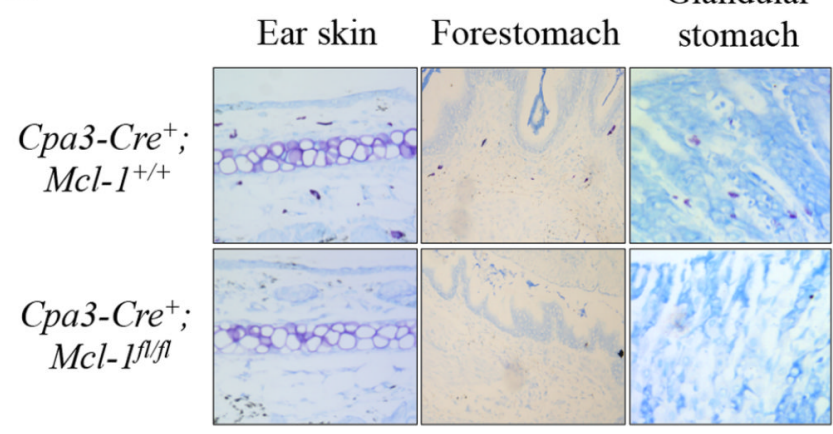

$\mathrm{Cpa3}_{-\mathrm{Cre}}{ }^{+} ; \mathrm{Mcl}^{-\mathrm{I}^{+/}}$

E $\quad \mathrm{Cpa3}_{-\mathrm{Cre}}^{+}$;

$\mathrm{Cpa}-\mathrm{Cr}{ }^{+} ; \mathrm{Mcl}-\mathrm{Iflfl}^{\mathrm{fl}}$

D
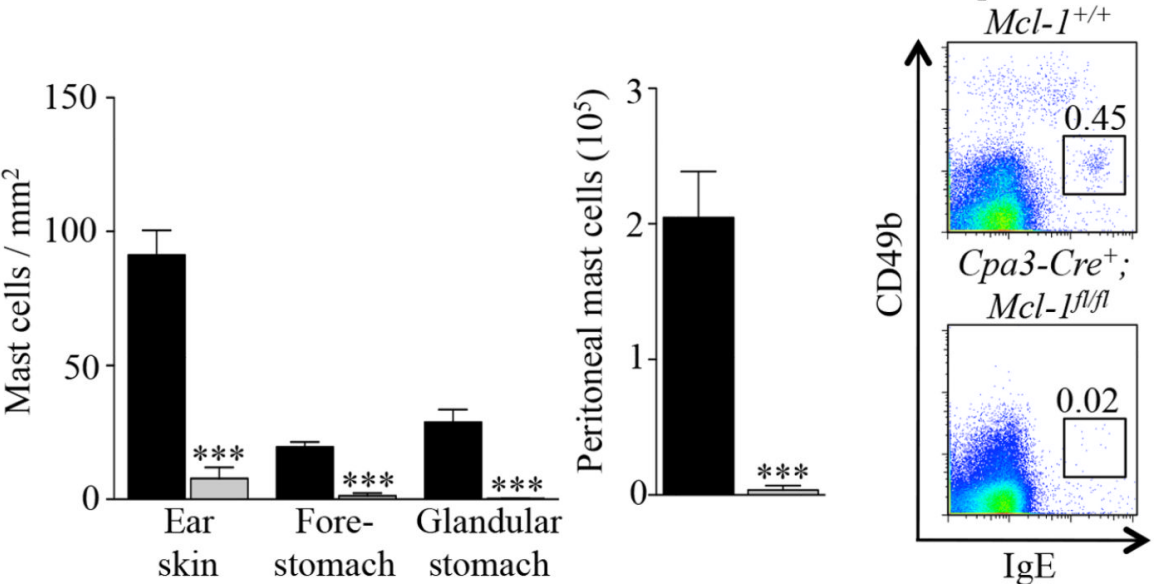

F
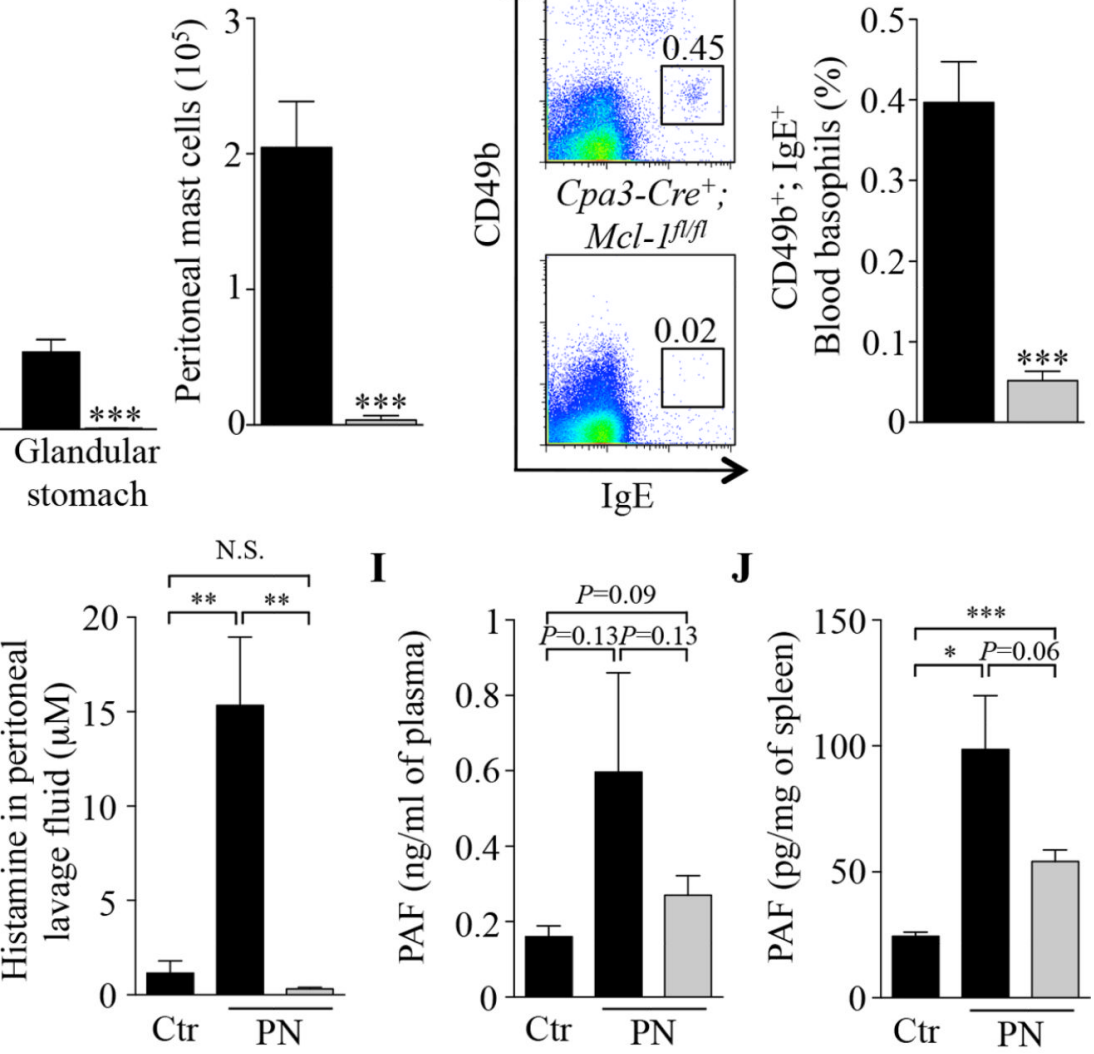

I

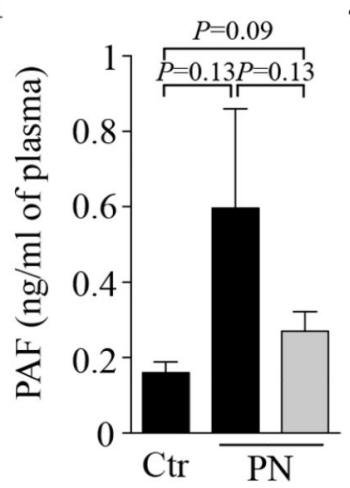

$\mathbf{J}$

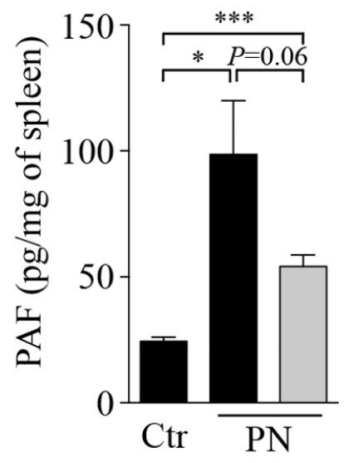

FIG 5. Peanut-induced anaphylaxis in $\mathrm{Cpa3}_{\mathrm{Cre}}{ }^{+} ; \mathrm{Mcl}-\mathrm{I}^{f l f l}$ mast cell- and basophil-deficient

(A) PN-induced hypothermia in PN-sensitized $\mathrm{Cpa3}^{-\mathrm{Cre}^{+}}$; $\mathrm{Mcl}^{-1^{++}}{ }^{(n=6)}$ and $\mathrm{Cpa3}-\mathrm{Cr} \mathrm{e}^{+}$; $\mathrm{Mcl}^{-1} \mathrm{I}^{\mathrm{fl} / \mathrm{fl}}(n=7)$ mice. $(\mathbf{B}-\mathbf{C})$ Toluidine blue staining for MCs $(\mathbf{B})$ and numbers of MCs $(\mathbf{C})$ in sections of ear skin, forestomach and glandular stomach. (D) Numbers of MCs in the peritoneal lavage fluid. (E-F) Representative flow cytometry plots (E) and percentage (F) of

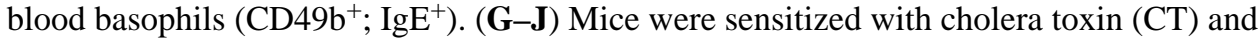
PN (PN; $n=5-7$ ) or CT only for control mice (Ctr; $n=3-4)$, and sacrificed 20 min after challenge with PN to measure levels of histamine and PAF. (G-H) levels of histamine in plasma (G) and peritoneal lavage fluid (H). (I-J) levels of PAF in plasma (I) and spleen 
samples $(\mathbf{J})$. Data are mean \pm SEM or mean $+\mathrm{SEM} ; *$, ** or $* * *=P<0.05,0.01$ or 0.001 VS. corresponding control group. 